\title{
Distance Learning of a Foreign Language - Necessity or Future
}

\author{
https://doi.org/10.3991/ijet.v16i04.18299
}

\author{
Nataliya Kolyada $\left({ }^{\bowtie}\right)$, Larisa Shapovalova, \\ Yuliya Guz, Ashkhen Melkonyan \\ Southern Federal University, Rostov on Don, Russia \\ kolna@inbox.ru
}

\begin{abstract}
In order to effectively organize the educational process when teaching foreign languages remotely in the context of a pandemic, special technical, psychological, and pedagogical training is required to switch to this form of education. Thus, it is necessary to study the current state of distance learning in foreign languages, both in Russia and abroad, and analyze the prospects for the development of this form of education, taking into account factors that have a positive impact on the process of learning a foreign language. The purpose of the article is to identify the theoretical and methodological foundations of distance learning in foreign languages, analyze the factors that have a positive and negative impact on the process of learning a foreign language, and determine the role of a teacher who organizes the process of teaching foreign languages remotely. To solve the problems of the research, a set of research methods was used: system, historical, theoretical analysis and generalization of literature, questionnaires. Statistical data processing was carried out using Google services when conducting surveys used for analyzing and summarizing data, their graphical visualization the results Of a survey of students in one of the leading universities in Russia in the form of distance education revealed positive aspects about the introduction and implementation of distance learning, however, the data obtained on the quality of distance learning agreed, that "live" interactivity in the classroom with classmates and other participants in the educational process leads to the highest results of communicative teaching of foreign languages. As a result of the research on the quality and interest of students and undergraduates in distance learning, 180 students aged 18 to 25 years were interviewed. A retrospective analysis of the development of distance education in Russia and abroad revealed such facts that not all countries were ready to switch to this form of education during the pandemic. Based on the experience of working in the form of distance learning of foreign languages, this article offers the main ways and methods of teaching a foreign language that can be applied in international practice of teaching foreign languages remotely.
\end{abstract}

Keywords-Modern information society, introduction of distance education in Russia, online training 


\section{Introduction}

Today, the modern world community imposes appropriate requirements to a specialist not only in terms of their professionalism, their competence in the field of employment, but also to knowledge of foreign languages [1,2]. Expanding contacts in all fields of science and technology, symposiums, conferences, business partnerships, both in the field of production and in the field of service, and recently tourism, indicate the urgent need to master a foreign language, especially by specialists $[3,4]$. Is not a secret that a foreign language allows, first and foremost, be knowledgeable on new developments in a particular field of science, promotes rapid understanding affects productivity collaboration helps to build trust and, not least, promotes a healthy climate. The advantages of knowing a foreign language can be enumerated indefinitely [5-7]. The question is how to learn a foreign language, and whether it is available to everyone.

The so-called phenomenon of foreign language proficiency has long been studied by both linguists and psychologists; whole theories and prescriptions are being built, and a number of methods are being proposed. However, this is not a panacea for learning a foreign language. An important factor in this case is a genetic predisposition, a kind of linguistic talent, and an important one is hard work, which includes consistency, regularity and, of course, desire [8].

The main methods of learning foreign languages that exist and are currently offered are, as a rule, self-study, group classes, individual classes, the so - called artificial immersion in the language environment, as well as the use of video and audio courses, and Express classes (intensive courses) $[9,10]$. Each of these methods has its advantages and disadvantages, but each of them does not provide for a quick, as if self-evident, easy mastery of a foreign language. Without systematic training, without cramming grammatical rules, lexical content, no method will work [11-13]. The longest and not everyone is amenable to the method is self-study. You can learn to write, read, and translate on your own, but to master oral speech, you need a communication partner, without whom it is impossible to learn to communicate in a foreign language [14-16]. A partner can be a teacher, a native speaker, who can be found today via the Internet, which in modern society is a plus when learning foreign languages $[7,11,12,17]$. However, this way does not guarantee the correct phonetic design of oral speech and the correct use of grammar, and lexical units with their polysemous meanings, since the student must sometimes guess about the application of a particular rule, in other words, a consultant is needed, that is, a teacher [11]. Teachers of foreign languages insist on learning a foreign language in groups, considering this method the most effective and affordable. The latter is questioned not only in terms of human abilities, but also taking into account the fact that not everyone who wants to learn a foreign language, has the opportunity to attend group sessions, such as courses or study at universities specialized faculties [8].

At the beginning of the 21st century, some universities in Russia (for example, the Modern Academy of Humanities) have such a type as distance education. The educational process involved the initial work of teachers with students, with explanations and explanations of new material, while taking into account the opinion of practition- 
ers that the development of communicative grammar is possible within 10 classes [18]. Then the students had to work on this material independently with the available technical means (audio and video recordings). Unfortunately, it turned out that the number of hours for group classes is extremely minimal, and this affects the quality of knowledge, since students studying with this type of education do not all have the potential that is necessary for learning a foreign language. Despite the fact that the program of distance learning of foreign languages includes a group method of learning a foreign language, and independent, and individual using audio and video recordings with the subsequent control of the teacher of students ' knowledge, and even a student exchange program, however, the final result does not justify the hope of mastering a foreign language. As it turned out, after graduation, students do not know how to communicate in a foreign language, not getting enough speech practice, since most of the training is aimed at independent learning of a foreign language. In the system of distance education, University graduates, unfortunately, more mastered the translation of texts both artistic and scientific (within a certain specialty) [8].

The COVID-19 virus disaster has affected the lives of people around the world. Rapid changes have made it necessary to optimize many life processes, including education at all levels of education. And if the discussion about the introduction of remote digital technologies in curricula and programs constantly ran into the opinions of teachers about the impossibility or inefficiency of implementing distance learning, then in a few weeks the majority was forced to realize and accept the fact that this format has its own right to exist and even more, to replace classroom work with students remotely. Will this be a temporary, partial replacement, or is it already possible to predict the new future of the academic communication environment? To answer these questions, a survey of students and undergraduates from one of Russia's leading universities was conducted.

In the context of the pandemic, all educational institutions in Russia were forced to switch to distance learning. Training webinars were organized for teachers, explaining how to prepare and conduct lectures, practical classes in Microsoft Teams, and how to track and control students' academic results. Microsoft Teams is one of many online platforms where you can upload training content, develop tasks and tests, and conduct video conferences, which allows teachers to organize a dynamic learning environment. To do this, groups are created for collaboration, "teams", in which teachers and students are centrally united in professional educational communities and meet at "meetings" scheduled as part of the curriculum. It is undeniable that this educational paradigm is different than before, in which the teacher and the student take new positions in the educational process, they become partners in professional communication, which contributes to greater independence and activity of students in finding the necessary knowledge and reproducing their own results as a result of processing the information received. But educational efficiency is achievable only with a properly organized psychological and pedagogical process behind a computer monitor.

The purpose of the article is to establish the fact of accessibility of studying any subject, and in particular, a foreign language in the form of distance learning.

The task is seen in the analysis of acceptable ways and types of teaching foreign languages. 


\section{Research Methodology}

\subsection{Research methods}

This scientific research is based on the use of a set of theoretical and empirical methods. Systematic method helped to identify the components and strategic communication distance learning; to identify the factors exerting positive and negative effects on the learning process in distance learning format; evaluate the role and place of remote training in the process of learning foreign languages; to identify the role of the teacher in the educational process in distance learning format; formulate conclusions based on the results of the study that have a pronounced practical orientation.

The historical method assumed the study of the development of distance education, allowed us to present a retrospective analysis of the development of distance education in Russia and abroad, to detect trends in its further development [19,20].

Statistical data processing was carried out using Google services in conducting surveys used for analyzing and summarizing data and their graphical visualization.

\subsection{The survey}

Data collection was conducted by interviewing students of the SFU who study German as a foreign language. At the preparatory stage, the purpose of the survey was determined - to identify how students evaluate the quality of the proposed educational services for distance learning of a foreign language (German) and the degree of satisfaction with learning in this format. A questionnaire was developed. The classification of the questionnaire questions was based on three criteria: content, form and function. Based on the logic of the study, the number of questions was optimal, the answers to them provided complete information [21-27]. The survey was conducted in June 2020, for three days; the respondents were 280 students of the SFU bachelor's and master's programs aged 18-25 years, studying German.

\subsection{Data analysis}

Based on the results of the survey, we can conclude that students have a positive attitude to the introduction and implementation of distance learning, but $63 \%$ of respondents consider distance learning as an auxiliary and temporary training; students highlight the advantages of the distance learning format, primarily the flexibility of the educational process - 69\%; emphasize the importance of skills in using distance educational technologies obtained in the process of e-learning for further professional activities $-81 \%$.

In the process of discussing the results of the study, a number of disadvantages were highlighted: the lack of live social communication, the lack of face-to-face dialogue, and physical static in training. Good technical equipment of all subjects of training is considered promising $-45 \%$. 


\subsection{Statistical analysis of data}

The maximum statistical error of the survey results is $\pm 3.5 \%$ for a sample of students studying German.

\subsection{Ethical restrictions}

The received responses were analyzed and processed using Google services in conducting surveys; they served as the basis for identifying trends in the development of distance learning in foreign languages and drawing conclusions from the results of the study. All survey data was obtained with the consent of the respondents.

\subsection{Research restrictions}

When studying the assessment of the quality of the offered educational services for distance learning of a foreign language (German) and the degree of satisfaction with learning in this format, 280 questionnaires were evaluated, which is a fairly reference sample.

The following research limitations are highlighted:

- Students' assessment of the quality of the German language learning process in the distance learning format and the degree of satisfaction with learning in this formatsubject

- 280 respondents-Quantitative parameters

- SFU students studying German - A qualitative indicator

- Distance learning is a learning format

Distance learning as a new form can complement any form of training at a distance as a unique opportunity to acquire knowledge, learn to work independently and plan your time.

When teaching foreign languages remotely, many didactic tasks are solved with the help of new technological capabilities, complementing traditional methods of teaching foreign languages [Methodenmix-10 Wege, eine Sprache zu lernen [28]

The conducted research (at the end of the academic year, namely from March to July) suggests that not all types of work in teaching foreign languages could be effectively used. Many of the traditional types of work were completely excluded, and translation methods proved to be of little use.

Active and interactive methods were used effectively. The first ones include game exercises $(30 \%)$, Olympiads, presentations $(40 \%)$, and group consultations. Interactive methods were particularly effective $(60 \%)$, since their implementation was allowed by innovative technologies. in addition, such methods not only activate the work of students, but also increase motivation for learning a foreign language; and the main factor in this method is that classes are fun and interesting [29].

This method allowed us to use such forms of organization of educational work as individual, pair/group and collective. Such forms of work had a positive impact on the 
culture of communication and an adequate response to the interlocutor. Ability to work in a team [30].

When using interactive methods of teaching foreign languages, special attention was paid to independent work, the main principle when teaching remotely [31].

\section{$3 \quad$ Results}

\subsection{Implementation of distance education in Europe, in the United States, and in Russia}

The rapid development of information technologies in the modern information society is changing the strategy of education with the use of new information technologies that appear again and again, such as connecting a computer to the Internet and other gadgets. This format is increasingly gaining strength in the field of distance education.

More than half of us universities have accumulated experience in implementing distance education since the 90 s of the last century. Since the 70s of the last century, the University in Hagen and the Institute in Tubingen (Germany) have been working in this direction. Universities in Sweden, Finland, Turkey, Australia, Switzerland, China, Korea, and Japan are also making efforts to use distance education technologies.

In Russia, the process of implementing distance education was hindered by a number of reasons: insufficient material and technical support not only in universities, but also a shortage of computer equipment at home for students and teachers, school teachers. Gradually, separate training courses with the use of multimedia tools, video conferences, and Olympiads are being introduced into the training process.

The so-called online learning appeared in Russia closer to the second decade of the 21 st century and meant "e-learning" [32], which involves obtaining knowledge in all possible formats available to the student in this mode. This includes text with hyperlinks, video, audio, games, and other tools to achieve the goal.

It should be noted in this regard that the demand for educational services is increasing in the modern world. Distance learning is becoming more popular, which can sometimes be forced depending on the situation on the planet. But if online learning involves a "here and now" lesson and is limited to the fact that the student only listens, performs the task, but is deprived of the opportunity to communicate. Distance learning also includes "online", although the principle is the same-at a distance, but offers the opportunity to communicate with the teacher [32]. It is through distance learning that distance education is implemented.

Research shows that in the process of distance learning there are 5 General didactic methods of teaching, as in the traditional one, the so-called "information-receptive, reproductive, problem presentation, heuristic and research" [33]. For distance learning, teachers and practitioners recommend a range of methods, including demonstrations, illustrations, stories, conversations, exercises, repetition of the material, etc. As 
a means of implementing distance learning, books are called both in paper form and in electronic form, and online educational materials, and video - audio materials.

Scientists-practitioners who are engaged in the implementation of distance learning in the educational process, are unanimous in the advantage of this type of training. Among the positive aspects of distance learning, the following are highlighted in the first place:

1. Reduce transportation costs and time to attend classes in the classroom

2. Individual learning rate, which the student can adjust by himself

3. Flexibility and freedom of choice of subjects that are particularly important for the student

4. Availability at any time and from any location

5. Comfortable conditions for the student's classes

6. Objectivity in assessing the student's knowledge through online testing

7. Wide coverage of any category of the population, etc.

However, you should pay attention to the fact that the burden falls on the shoulders of a teacher who participates in distance learning. The teacher in this process, whether it is a distance or traditional form of education, is the main actor in the unfolding educational process. In order to efficiently and effectively provide the educational process, the teacher must, first, be equipped with the required technical base, and secondly, have "blanks" for conducting classes, such as: demonstration of a certain training film for the development of certain skills, presentation of educational materials that must be provided either in electronic form or in the form of attached files, develop a number of situations to encourage conversation, dialogue, monologue, a number of exercises to consolidate or repeat new or passed material, etc.

In many countries that have introduced distance learning in the educational process, the term "tutor" is used for the teacher, a kind of teacher-consultant, instructor, and coach. The need to introduce such a term in Russian practice has appeared relatively recently and is not yet everywhere. At the same time, it should be emphasized that the main task of the tutor is to manage the independent work of students, which, in turn, entails the performance of certain functions of the tutor. This includes the formation of motivating motives, setting goals and objectives, transferring knowledge and experience, organizing interaction between students, and monitoring the learning process and the quality of knowledge [34].

\subsection{Statistical data. results of a survey of students and undergraduates of one of the leading universities in Russia}

As a result of the research conducted at the southern Federal University on the quality and interest of students in distance learning, 280 students of various courses and structural divisions were interviewed, the results were discussed by teachers of the entire Department in an open discussion about the future prospects of unforeseen innovations in education. Since the survey was conducted on the initiative of teachers of the Department of German Philology, it is possible that the results obtained relate primarily to online German language training. The respondents were asked to answer 
10 questions and evaluate the quality of the offered educational services for distance learning of a foreign language and the degree of satisfaction with studying at the University, specify the educational, methodological and technical problems of this educational format. It was also necessary to find out whether students consider the distance format as an alternative to classroom classes. The questionnaire was compiled and conducted by SFU teachers who provide distance learning in order to improve its quality. The age of the students surveyed is from 18 to 25 years old, all of them living in the southern part of Russia, including young men and women who are seeking a bachelor's or master's degree from a leading University in the country. 280 questionnaires were received within 3 days. Subsequent statistical processing of data was carried out using Google services in conducting surveys used for analyzing and summarizing data and their graphical visualization. Here are examples of some of the questions and answers in this survey (Table 1).

Table 1. The examples of the questions and answers in the survey

\begin{tabular}{|c|c|c|c|c|}
\hline No & Questions & Yes & No & $\begin{array}{c}\text { I find it Difficult } \\
\text { to answer }\end{array}$ \\
\hline 1 & $\begin{array}{l}\text { Do you think the virtual classroom in Microsoft Teams is convenient } \\
\text { enough for learning? }\end{array}$ & $77 \%$ & $11 \%$ & $12 \%$ \\
\hline 2 & $\begin{array}{l}\text { What tasks do you think e-learning solves? } \\
\text { - Provides the opportunity to study at a convenient time and place } \\
\text { - Develops skills to work with volumes of information, develops } \\
\text { independence in finding and using the necessary information }\end{array}$ & $\begin{array}{l}59 \% \\
49 \%\end{array}$ & & \\
\hline 3 & $\begin{array}{l}\text { What advantages of e-learning are most important to You at the } \\
\text { moment? } \\
\text { - Training in a comfortable and familiar environment } \\
\text { - Flexibility of the educational process }\end{array}$ & $\begin{array}{l}69 \% \\
47 \% \\
\end{array}$ & & \\
\hline 4 & $\begin{array}{l}\text { Do you think that the skills of using distance learning technologies } \\
\text { obtained in the course of e-learning in your chosen specialty are } \\
\text { necessary in your future professional activity? }\end{array}$ & $81 \%$ & & \\
\hline 5 & $\begin{array}{l}\text { Please indicate the best ways for you to interact with the teacher } \\
\text { - Combination of tools: screen broadcast, group chat and audio } \\
\text { conference, shared documents in cloud servers }\end{array}$ & $61 \%$ & & \\
\hline 6 & $\begin{array}{l}\text { How do you assess the use of e-learning at the University? } \\
\text { - As an auxiliary or temporary training } \\
\text { - As basic training }\end{array}$ & $\begin{array}{l}63 \% \\
28 \%\end{array}$ & & \\
\hline 7 & $\begin{array}{l}\text { Will the quality of your education be Improved by using e-learning } \\
\text { on an ongoing basis? } \\
\text { - Yes, with good techniques } \\
\text { - Yes, provided that all subjects are well equipped with technical } \\
\text { equipment }\end{array}$ & $\begin{array}{l}34 \% \\
45 \%\end{array}$ & & \\
\hline 8 & $\begin{array}{l}\text { Please specify which types of devices You use for remote training? } \\
\text { - Mobile phone } \\
\text { - Laptop }\end{array}$ & $\begin{array}{l}84 \% \\
70 \%\end{array}$ & & \\
\hline
\end{tabular}

Analysis of the percentage of responses does not require detailed explanation: the positive and negative sides of the new format, as well as its potential in future education, are quite transparent According to this survey, the answers about the role of 
distance learning in the future are obvious. Quite a lot of positive opinions about the introduction and implementation of distance learning say this, there are only instructions and recommendations from students about improving online learning, which should be followed by Tutors. First of all, it is the use of high-quality Internet connection, good audio and video to provide instant feedback. A clear advantage for students is a convenient and familiar "home" format of training, which causes a positive psychological mood, and as a result, a high motivation for active participation in the class. This is also confirmed by the attendance of online classes: it has become better. The distance format develops independence in finding and using the necessary information, which contributes to the flexibility and autonomy of the educational process. A particularly convenient form of communication between a teacher and a student is a video conference with group chat, screen translation and joint processing of documents in cloud technologies. All these skills, knowledge and skills are considered important by students in their future professional activities, but they still evaluate the distance format of classes as "auxiliary or temporary training", provided that they have good distance methods and good technical equipment.

According to the results of the survey, it is interesting that the majority of students enter online classes using smartphones, rather than computers, which indicates the transition to mobile learning. Due to the usual and cost-effective Internet access, the mobile learning approach is popular in Central European and Anglo-American societies. A tablet or smartphone is a portable, universal tool for the younger generation, with which the use of popular media guarantees high motivation in the educational process outside of a strictly regulated educational context.

It should be taken into account that each student spends several hours a day in a portable mobile device, which, of course, must be taken into account when motivating students to study. In discussing the study, it was suggested that it would be possible to add a few questions about the assessment by students of their remote operation, for example, how consciously and independently performs control tasks to assess the learning outcomes of or do you manage students effectively plan educational activities on a daily basis, week, month, etc. According to most opinions of foreign language teachers, the biggest drawback of the distance learning format is the distance between people who conduct a dialogue. The next disadvantage that is associated with the first one is the physical static in training. From communication in front of the screen, a person gets tired much faster, there is physical fatigue, which is bad for health and the quality of training. In addition, linguodidact scientists have proven the effectiveness of interactive forms of work in a foreign language class, when for an hour or two it is suggested to change not only the form, but also the mode of work, moving in the audience every 10-15 minutes. Changing modes is carried out through mobile, role-playing, collective games. Without simulating life situations in which it is impossible to sit in one place as in a remote format in front of a screen, it is difficult to realize the main communicative goal of learning a foreign language, namely, live communication with representatives of other cultures. The absence, role and importance of social communication "live" is undeniable, which cannot be replaced by any form of distance learning. Live communication, an interlocutor with smiling eyes, life around you - this is a mutual positive energy and priceless elements of communi- 
cation between people and cultures. All teachers in the discussion and evaluation of the results of the survey of students on the quality of distance learning agreed that "live" interactivity in the classroom with classmates and other participants in the educational process leads to the highest results of communicative teaching of foreign languages.

\subsection{The availability of distance learning}

An important question is whether any subject is available for study in the form of distance learning. If this is a theoretical subject, in which it is enough to convey knowledge to students through lectures, seminars, video lectures, colloquiums, solving problems in mathematics, physics, chemistry, biology and other disciplines of the educational process, then this form of training takes place. However, for a subject that is aimed at developing speech activity, namely, the development of skills and abilities of speaking, listening, reading, writing, translating, and finally, fiction and scientific literature, the style and language of which is completely different from spoken speech, additional teaching methods are required. Moreover, the amount of classroom work is very different from the amount of independent work. In the context of the pandemic, the fact that Russian students are not trained to work independently has once again been confirmed. The form of distance learning revealed the disadvantages of working with texts, the translation of which was completely unsuitable for independent work, because the student uses an Internet translator, and the teacher checks the translator, not the student. In language specialties, where techniques and methods of translating works of art are practiced, distance learning does not justify itself. The same applies to non-language specialties, when the teacher works in the classroom with each student individually and explains their mistakes, which is biased in the distance learning format. After all, the student will always look for and find dishonest ways to get a good answer. Therefore, such a type of work as translation from a foreign language into a native language, which is necessary for a specialist who uses new achievements in their research, is completely excluded from the Program. The conclusion is that in the conditions of distance learning, the probability of falsification of training and, accordingly, control over the educational process at a distance may increase.

All theorists and practitioners on the implementation of distance learning emphasize two important factors: the independence of the student and his motivation.

\subsection{Prerequisites for a positive result in distance learning}

As practice has shown, the student's independence in Russia is extremely low due to the weak will of many, lack of perseverance, lack of self-demands, a certain Russian laziness, lack of coordination, disorganization, inability to allocate their time. And during the distance learning period, there is no need to attend classes. In addition, the student speculates about a number of circumstances, both technical and domestic, namely, power was turned off, for example, the webcam was broken, the microphone does not work, etc. In other words, the student endlessly searches for reasons for their 
lack of preparation for classes, and the teacher is powerless to rely on the student's independent work.

Motivation. It is motivation is a powerful force in the framework of distance learning. Unfortunately, the motives for higher education are different. Someone just wants to get a diploma, no matter what specialty, the main thing is to have a higher education. Someone is studying because they entered the University at the initiative of their parents, the student did not make this choice himself, so he is not interested in studying, but he is forced to finish this particular University. And only an extremely small category of students in Russia seeks knowledge, acquire skills and abilities in their future specialty. The practice of working with students shows that many of the latter category consider distance learning as an additional education that can be obtained without leaving home. Unfortunately, there are only a few such students. As a rule, those individuals who set themselves the goal of mastering a foreign language for further study abroad, either in a master's degree, or in a postgraduate course, or for an internship are motivated. Another category of persons = are those who apply for residence abroad. It is these two categories that show independence in work, concentration, and a desire to engage in training in such a form as distance learning. However, the question of the size of the group should be emphasized. It is recommended to divide the group into subgroups, which should not exceed 3-4 people in order to work actively. It is in this case that classes are held productively and effectively.

An important issue when teaching a foreign language in the form of distance learning is the selection and selection of educational material, since during distance learning, both the essence and content of traditional elements are subject to change and there is a need to search for new elements. Such a subject as a foreign language does not correspond to the traditionally accepted organizational forms of learning in the distance learning mode, i.e. in contrast to theoretical subjects, where lectures and seminars take place, classes in a foreign language are practical, where the skills of speaking, listening, and writing are laid down and improved. What educational material can be offered in this case with the use of all the latest information technologies to achieve interactive interaction between students and teachers?

\subsection{Expected types of work on mastering a foreign language in the form of distance learning}

The best help in foreign language classes is video and audio materials, which are accompanied by tasks for further discussion and discussion. However, these tasks must not only be prepared in advance, but also attached to the team on a specific platform where the classes will take place. In this case, the work is aimed at speaking and listening, and the goal may be monological and dialogical speech. At the same time, the phonetic, grammatical, and lexical design of speech is worked out.

Many e-learning programs, in addition to video conferences and file attachments, provide the ability to use virtual whiteboard technology, which is available to all participants of the conference or study group. This function can be used in the classroom, i.e. you can write and indefinitely erase explained examples on the blackboard, emphasize the necessary components in the design of either a sentence, or the temporary 
form of a verb, or declension of adjectives, nouns, or complex syntactic structures. The virtual Board is suitable for writing new rules, transcription, and explanation of vocabulary [35]. For example, a Microsoft whiteboard provides a free digital canvas feature that is integrated in Microsoft Teams meetings. This requires a whiteboard web application that allows meeting participants to write and draw together on a shared sheet. The teacher can grant access to the blackboard so that it is available not only during the class, but also offline to all students in this group [36]. Applications with collage boards deserve attention, there are a lot of them developed today. One of the most popular Pinnwand Padlet is a whiteboard (virtual whiteboard), but with the ability to pin texts, photos, images, links, and other multimedia files to it [24]. When preparing for a lesson, the teacher creates a virtual Board in Padlet on a specific topic. In active interaction, students enter words, texts, insert pictures, which undoubtedly motivates them to communicate in a foreign language. It is very convenient for the teacher to do a survey, the results can be used when discussing a topic or for organizing a discussion, later you can process and fix the training material as a homework [37].

This type of work is well justified, such as untrained interpretation of individual sentences on the studied lexical and grammatical material. However, it should be emphasized that this type of work is effective only if the student does not use an Internet translator, which is common among Russian students. Therefore, working in student groups that reach 12-15 people, and this is the norm in Russia when forming student groups for learning a foreign language, it is unrealistic to follow this process, since it is impossible to see the entire group on the screen. This is one of the negative aspects of learning a foreign language in the form of distance learning.

As part of the development of monologue speech skills, project activities have long proven themselves. In our opinion, the project learning method was a kind of harbinger of modern distance learning, the project Method, also known as project learning or project work, is one of the most discussed teaching methods today. Thus, scientists [38] believe that this method contributes to the formation of a special way of thinking, which is called the project style of thinking. The German scientist M. Knoll believes that this method of teaching is based on practical problem solving and requires students to work independently and constructively on a larger scale [19]. Domestic theorists and practitioners emphasize that the project method not only develops students ' creative and research activities, but also forms their information and communication competence [39]. It should be noted that students with great inspiration are involved in this type of work, which involves searching the Internet resources for the necessary material, its processing, and design of the project, followed by a presentation in the classroom in the group. In the age of digitalization, young people perfectly cope with all the technical and electronic means available to them, demonstrating their information and communication competence. However, in the context of distance learning, the goal that the teacher sets for students may not be achieved, namely: the message must be oral, thus developing speaking skills. But the student may have a currently crashed webcam, for example, and the teacher does not see the student on the screen. The student can simply read his message, it is good if it is pre-read at least with the 
correct pronunciation, with the placement of all the accents in the words, as well as phrasal accents. Often, the student reads their message from the page.

This type of speech activity as reading also has its "pros" and "cons". If reading is considered as practicing pronouncing skills, then this achieves its goal. But if we consider the reading as an introduction to the subsequent tasks, then to check how independently the student read the text without resorting to a" translator", and independently completed the task to the text, it is not possible for the teacher to be objective. The student will always find an opportunity in additional Internet services to earn an assessment for this type of work. And in terms of distance learning, this is possible, since the student has access to all electronic media.

Working on developing writing skills also has two sides, positive and negative. A responsible, organized and motivated student will try to complete the task on their own and get recommendations from the teacher, what mistakes should be corrected and why they should be corrected in this way. Most of the students will speculate when completing this task.

In the form of distance learning, such forms of work on the development of speaking and listening skills as holding conferences are also acceptable. Any prepared report (message) of students assumes it when accompanied by a presentation. It is in this case that the project activity discussed above is applied to the person.

Students are especially welcome to meet at a round table with native speakers who report on the country's cultural events, introduce them to the living conditions in the country, and share their impressions of their stay in Russia. Students are happy to engage in a dialogue with an invited guest, ask questions, and Express their opinions. This type of work is a good incentive for learning a foreign language.

Conducting quizzes and Olympiads, in our opinion, is ineffective, since the student "dives" into the Internet and searches for answers. This type of work can only be offered in advanced groups, among interested students in learning a foreign language. More acceptable in this regard is online testing, which must necessarily be limited in time.

A great difficulty in this form of learning, such as distance learning, is the introduction of grammatical material. The teacher must have all available technical means to demonstrate grammatical rules in the foreign language being studied on the screen. It should have such technical means that would replace the interactive whiteboard. The teacher needs to develop an algorithm for introducing grammatical material that will be accessible and understandable to every student. But it is no secret that many people require a more detailed explanation, since the level of perception and understanding is different for everyone. In the classroom, you can write and indefinitely erase explained examples on the blackboard, emphasize the necessary components in the design of either a sentence, or the temporary form of a verb, or the declension of adjectives, nouns, or complex syntactic structures. This once again highlights the difficulties of not only implementing innovative technologies for implementing the distance learning process, but also confirms the fact that it is becoming very timeconsuming to prepare a teacher for classes.

It is also necessary to touch upon such type of work as translation from a foreign language into a native language, especially scientific texts. This type of work is typi- 
cal mainly for groups of postgraduates who are preparing to pass the candidate's minimum in a foreign language. Check the independence of performing text translation in the remote form of training showed a complete fiasco. A graduate student who could barely translate a couple of sentences with a dictionary demonstrated excellent translation in a distance learning class. The conclusion was clear - the graduate student did not translate the text independently, trying to deceive the teacher, in fact, the graduate student was deceiving himself, not trying to understand all the subtleties of translating a scientific text. The same picture is presented to us when working on a scientific text that should be read without a dictionary and briefly convey the content of the text in a foreign language. In the classroom, a graduate student can be observed whether they do this work on their own or use the Internet over the phone. As part of distance learning, a graduate student compiles a text in their native language and then translates it online. The conclusion is that the graduate student no longer shows knowledge of a foreign language, but the ability to use all available technical and electronic means.

\section{Discussion}

The distance learning system is developing intensively all over the world due to its integration ability. It should be noted that the European educational community is increasingly using the practice of joint implementation of educational programs, as well as tasks related to the management of the distance learning system. And the governments of European countries themselves are interested in developing this form of education. But the important point here is that different countries pursue different goals when using this type of training, in addition, the contingent in these countries differs significantly. In the UK, for example, it is used more for training immigrant professionals to adapt and integrate faster. In the United States, distance learning was initially used for people who have health problems or do not have enough time to attend traditional University classes. This opportunity was also used by those who were limited in financial opportunities. In Germany and the Netherlands, this form is most often used for teaching students, therefore, distance learning is widely represented in universities. The key point is that the educational programs created in the universities of these countries for this type of training are of great value for certain groups of students. The content of academic disciplines is developed by the joint efforts of the teaching staff, or for this purpose, experts from outside are involved. But even in such economically developed and financially prosperous countries, there is a lag in the implementation and transition to advanced technologies [40]. Various programs are offered for the duration of study: from two years without a degree, to two or four years with a bachelor's or master's degree. As for multimedia technologies that are used in distance learning, the most common, for example, in America, are twoway video communication and video carriers with recorded lectures [41]. But here we must mention some obstacles to the successful implementation of this form of training, such as the high cost of such programs, failures in the operation of equipment and networks, etc. 
It is inevitable that universities around the world make their own adjustments to the educational process, which uses the latest technologies (pedagogical, information, technical, etc.). And even with the same requirements for distance learning, it is impossible in any case not to take into account its specifics related to the geographical, ethnic, cultural and other aspects of a particular country. Educational traditions play a great role in this process.

In America, and in other countries of the world, people are increasingly talking about self-education. The point is that if a person is motivated to learn and has the ability, then they can independently, using the latest technologies, using multimedia training programs, which, for example, were developed by one of the most prestigious universities, get the desired quality education. However, the process will be successful if, according to foreign supporters of distance learning, the student will occasionally resort to the help of a tutor and participate in control activities [42].

Based on foreign and domestic experience, we should especially emphasize the importance of quality management of educational technologies. To improve the effectiveness of the distance learning process, it is necessary to use computer telecommunications, which are able to transmit the necessary information at any distance and in any volume, to conduct control measures in order to identify the effectiveness of quality management of pedagogical technologies used in each particular University, and also allow for interactive feedback, without which distance learning will turn into a process of self-education. Opponents of distance education around the world have great doubts about the fact that the knowledge and skills of those students who receive distance education are comparable to the knowledge of those who receive traditional education.

Many educational institutions around the world complain about the lack of suitable teaching staff for this type of training. In addition, scientific research needs to be reorganized. Therefore, the experience of foreign universities is valuable and can be partially used in Russian educational institutions. However, we cannot ignore the fact that the increase in the number of such educational institutions aimed at distance learning is primarily aimed at attracting additional funding from public and private structures, which will eventually lead to a transition from interactive learning to self education [32]. This will significantly affect the quality of education in General, as well as reduce the interest of the student and, consequently, significantly affect the educational component of the educational process.

In this regard, it should also be noted that distance learning in Germany is primarily aimed at such specialties as engineering, natural science, design, computer science, psychology, etc. Regarding the study of a foreign language remotely, the opportunity to learn grammar, lexical composition of the language, spelling, pronunciation is emphasized. But to master a spoken foreign language, you need a native speaker, that is, "live" communication [43].

As for such spheres of activity as business communication, a "face-to-face" dialogue is necessary, when gestures and the entire body of the interlocutor are involved, such as facial expressions, emotional expression, and so-called kinesics [20].

Distance learning in Russia began to develop at the beginning of the 20th century, but it was originally intended only as distance learning, in which students were pro- 
vided with the necessary material, had the opportunity to correspond with teachers, but had to come to the session. It was only at the beginning of the 21 st year that Russia was able to reach the international level in this direction. However, it should be noted that in other European countries and in the USF for almost more than 70 years, methodological materials, training programs with the involvement of the best specialists have been developed for this type of training [44]. In Russia, the system of distance education still does not reach the world level. The development of appropriate programs, training of teachers and teachers for online classes began during the pandemic. For example, a branch of the Customs Academy in one of the Russian cities switched to this type of training only from the middle of the semester, i.e. in the second half of April 2020. In this case, classes were held in the form of webinars, then the Zoom platform was involved, followed by the Microsoft Teams platform. Technically, the University was not ready to conduct classes in the form of distance education. In addition, many students were not equipped with appropriate equipment, communication with the teacher was constantly cut off, especially with those who went home to the region or to villages far from the city. This situation has led to absenteeism and a decrease in the level and quality of knowledge (Table 2).

Table 2. A survey of teachers of Udmurt state University (169 teachers) on the transition to distance learning revealed the following facts (some questions)

\begin{tabular}{|c|l|c|c|c|}
\hline No & \multicolumn{1}{|c|}{ Questions } & Positive & Satisfactory & Negative \\
\hline 1 & Readiness of teachers to switch to UP to & & $13 \%$ & $60 \%$ \\
\hline 2 & $\begin{array}{l}\text { Completion of advanced training courses to } \\
\text { work at UP to 63\% (but did not acquire skills) }\end{array}$ & $\begin{array}{c}63 \% \text { (but did not } \\
\text { acquire skills) }\end{array}$ & $13 \%$ & $16 \%$ \\
\hline 3 & Quality of organization of transition to UP to & $3 \% /$ good -33, 56\% & $41,63 \%$ & $14 \%$ \\
\hline 4 & $\begin{array}{l}\text { Technical and methodological assistance of the } \\
\text { University }\end{array}$ & $24 \%$ & $20 \%$ & $42 \%$ \\
\hline 5 & Quality of education & & & $80 \%$ \\
\hline 6 & Technical support & & & $90 \%$ \\
\hline 7 & Technical equipment at home & & & $50 \%$ \\
\hline 8 & Conducting the summer session (exams) & & $100 \%$ \\
\hline
\end{tabular}

In addition, the survey raised questions about increasing teachers ' pay, as the time spent on preparing for classes increased by $41 \%$; the need to train teachers regularly to work in the distance learning format. There was also a negative opinion about the universal transition to distance learning. For example, this system is not suitable for creative professions. It was emphasized that distance learning should not replace traditional education, but should complement it. When compared with the analysis carried out in this article about acceptable forms of distance learning, the opinions of teachers of the named University coincide - these are lectures, conferences, presentations. As for checking students ' knowledge, only testing and consultations (in the form of a dialogue) are also acceptable in this University [45].

When conducting a survey to assess the quality of e-learning and distance learning technologies at Kuban state technological University (3,010 students), it was emphasized that the majority of respondents (37\%) are neutral about this form of education, $33 \%$ perceive it positively, $29 \%$ chose the position "rather not", and $15 \%$ of the sur- 
veyed students expressed extreme dissatisfaction. Technical difficulties were noted, as in many Russian universities, such as unstable communication, sound quality, lack of a webcam, unexpected disconnection of a computer or laptop, problems with Internet access, and dissatisfaction with holding a summer session remotely [46].

According to data available to the Federal news Agency (Russia), most universities in Russia and many countries were not ready to switch to this form of education [47] during the pandemic. This transition led to this data to a stressful situation for both students and trainees. It was found that many Russian students do not have the equipment to study at home, or there is no Internet connection and suitable gadgets. In some countries, for example, in the United States, students were not ready to study at home, because the American method of teaching is designed for working in the classroom, not for homework $[25,48]$. Specialists in higher education institutions in Spain and other countries are also concerned about the decline in the quality of education.

We can safely conclude that distance learning in Russia today does not meet all the technical requirements. In addition, the lack of educational programs and training of teachers for this form of education negatively affects the entire educational process.

However, the advantages of distance education are undeniable, and they can be listed indefinitely. This is a motivating factor, and the formation of foreign language communicative competence among the General population, and an individual approach to learning foreign languages, and the introduction of information and communication technologies, and much more.

\section{Conclusion}

With the introduction of information and communication technologies in foreign language teaching, the teacher faces the task of mastering the existing modern technical means of teaching, finding new promising types of classes in a foreign language.

Distance learning of a foreign language requires appropriate training of the teacher as a coordinator when conducting classes at a new innovative level.

There is a need to create distance learning courses, in particular specially prepared electronic textbooks for each type of speech activity. To date, the existing educational and methodological complex has not been adapted to the training courses in the new training format.

The analysis revealed the fact that for a number of reasons, not all types of speech activity can be successfully and effectively worked out during distance learning of a foreign language.

The practice of working in this mode has shown that independent and individual work of students is more fixing and auxiliary, since the student, of course, should learn the material itself, which the teacher has presented to him. But sitting alone with a textbook, without talking, that is, without communicating, it is almost impossible to actively master the language. Therefore, the fact is confirmed again and again that the most accessible and effective way to master a foreign language is a group lesson, where the student can compare themselves with others, and understand their mistakes 
with the help of a teacher, and expand their vocabulary. However, it should be noted that groups for learning a foreign language should not be numerous.

Learning a foreign language only in remote mode should be limited, since many aspects of learning a foreign language are more effectively worked out in "live" contact.

Abuse of the use of only technical means, prolonged work at the computer leads to a decrease in health, reduced vision, a deterioration of the musculoskeletal system, a lack of habitual communication of people, which adversely affects mutual understanding and a healthy lifestyle.

Lack of technical capabilities of students due to expensive equipment (PC, laptop, Internet connection and other technical equipment), as not everyone can afford to buy the necessary equipment.

Thus, according to the analysis of possible forms and types of teaching foreign language in format TO revealed positive side - save time on trips to the students $100 \%$, however, negative aspects were: lack of preparation of teachers of Russian universities to move on TO $(60-70 \%)$, the deterioration of the quality of education and knowledge of students $(80 \%)$, insufficient technical equipment of teachers and students $(80 \%)$, the lack of qualification of teachers for the transition to distance learning $(90 \%)$.

Therefore, in order for distance learning to be successfully implemented in the educational process, the society must be prepared for the transition to this form of education, both technically, psychologically, and pedagogically. And in this process, a special responsibility lies on the state's activities in this matter.

\section{Acknowledgement}

This research was carried out within the framework of the programme to support the publication activity of the Southern Federal University.

\section{$7 \quad$ References}

[1] Berufe rund um Sprachen. https://www.einstieg.com/ausbildung/berufe-nach-themen/ berufe-rund-um-sprachen.html

[2] Belyakova, E.G. \& Zakharova, I.G. (2020). Professional Self-Determination and Professional Identity of Students-Teachers in the Conditions of Individualisation of Education. The Education and science journal, 22(1): 84-112. (In Russian) https://doi.org/10.17853/19 94-5639-2020-1-84-112

[3] Guetl, C., Chang, V., Edwards, A., \& Boruta, S. (2013). Flexible and affordable foreign language learning environment based on Web 2.0 technologies. International Journal of Emerging Technologies in Learning, 8(2): 16-28. https://doi.org/10.3991/ijet.v8i2.2488

[4] Eurovoice $\mathrm{GmbH}$ (2020). Informationen zur optimierten Arbeitsweise bei der Vertonung von Video -/CD-Präsentationen in Fremdsprachen. http://www.euro-voice.de/fileadmin/ images/pdfs/Kundeninfo-Fremdsprachenvertonung.pdf 
[5] Ni, D. (2017). Design and research on English listening teaching assisted by computer multimedia. International Journal of Emerging Technologies in Learning (iJET), 12(01): 32-43. https://doi.org/10.3991/ijet.v12i01.6053

[6] Sprachen \& Beruf (2012). Berufliche Vorteile durch Fremdsprachenkenntnisse. https://on line-sprachen-lernen.com/berufliche-vorteile-fremdsprachenkenntnisse/

[7] Linda, N. (2018). Wie wichtig sind die Fremdsprachen im Beruf? LaL Blog. https://www. lal.de/blog/wie-wichtig-sind-fremdsprachen-im-beruf/ https://doi.org/10.1515/978311159 $\underline{7966.38}$

[8] Kolyada, N.A. (2007). Foreign language and distance education. In the collection: The communicative paradigm in the Humanities. Materials of the XI international scientific and practical conference. RINYAZ, Rostov-on-don.

[9] Kuhnecke, A. (2017). Lernen mit Bewegung. TELC Language Tests. https://www.telc.net/ verlagsprogramm/ueber-telc/daf-blog/detail/news/lernen-mit-bewegung.html

[10] Thema: Fremdsprachenunterricht an der Uni vs Intensivkurs an der VHS. https://bfriends. brigitte.de/foren/fremdsprachen-forum/457938-fremdsprachenunterricht-an-der-uni-vs-inte nsivkurs-an-der-vhs.html

[11] Shuklina, E.A., Pevnaya, M.V. \& Shirokova, E.A. (2020). Adaptation Potential of Teachers of the Third Age in the Conditions of Higher Education Transformation. The Education and science journal, 22(1): 146-169. (In Russian) https://doi.org/10.17853/1994-5639-20 20-1-146-169

[12] Negovec, L. (2019). Sprachen lernen: Die besten Methoden \&Tipps. Allesprachen. https:// www.allesprachen.at/blog/sprachen-lernen/

[13] Abel, F. (2018). Traditionelle und alternative Unterrichtsmethoden. https://www.uni-gies sen.de/fbz/fb05/romanistik/didaktik/Team/prof/emeritus/prinz/bilder-und-datein/Traditione $\underline{\text { lle\%20und\%20alternative\%20Unterrichtsmethoden.pdf }}$

[14] DocCheck Flexikon (2011). Sprechen. https://flexikon.doccheck.com/de/Sprechen

[15] Sprechfertigkeit. Förderung der mündlichen Kommunikation im Fremdsprachenunterricht https://www.grin.com/document/323114

[16] Lewerken, A. (2008). Werkzeugliste Sprechen. Sprechen üben in großen Gruppen. GoetheInstitut Mailand. http://www.goethe.de/resources/files/pdf85/Werkzeugkiste Sprechen.pdf

[17] Sprachen lernen: 5 Methoden, 5 Tipps und 3 Fallstricke. https://www.lernen.net/sprachen/

[18] Van Lier, L. (1995). Introducing language awareness. Penguin English, London, England.

[19] Dela Pena-Bandalaria, M.M. (2010). E-education in the Philippines: trends, directions and challenges. Distance and virtual learning, 8(4): 495-510.

[20] Nähe und Distanz-Das richtige Maß bei der Gesprächsführung. https://www.absolventa.de/ karriereguide/koerpersprache/naehe-distanz\#: :text=Die $\% 20$ sogenannte $\% 20$ soziale $\% 20 \mathrm{Di}$ stanz $\% 20$ entspricht, $\mathrm{k} \% \mathrm{C} 3 \% \mathrm{~B} 6$ nnen $\% 20$ diese $\% 20$ sich $\% 20$ bedroht $\% 20 \mathrm{f} \% \mathrm{C} 3 \% \mathrm{BChlen}$.

[21] Baur, N., Blasius, J. (2014). Handbuch Methoden der empirischen Sozialforschung. Springer VS, Wiesbaden. https://doi.org/10.1007/978-3-531-18939-0 1

[22] Beller, S. (2016). Empirisch forschen lernen. Konzept, Methoden, Fallbeispiele, Tipps. Auflage, Hogrefe, Bern.

[23] Brosius, F. (2018). SPSS. Umfassendes Handbuch zu Statistik und Datenanalyse. Auflage, mitp Verlag, Frechen.

[24] Döring, N., Bortz, J. (2016). Forschungsmethoden und Evaluation in den Sozial- und Humanwissenschaften. Auflage, Springer VS, Wiesbaden. https://doi.org/10.1007/978-3-64241089-5

[25] Gräf, L. (2010). Online-Befragung. Eine praktische Einführung für Anfänger. Lit-Verl, Berlin. 
[26] Hug, T., Poscheschnik, G. (2015). Empirisch forschen. Die Planung und Umsetzung von Projekten im Studium. Auflage, UVK Verlagsgesellschaft mbH, Konstanz/München.

[27] Dick, M., Marotzki, W., Mieg, H. (2016): Handbuch Professionsentwicklung. UTB.

[28] Roth, C. (2019).Methodenmix - 10 Wege, Eine Sprache Zu Lernen. https://talkreal. org/blog/die-10-methoden-des-sprachenlernens/

[29] Geoman, G. (2017). Die 11 bekanntesten (und besten) Methoden, um eine neue Sprache zu lernen! https://www.sprachheld.de/methoden-techniken-sprachen-lernen/ .

[30] MosaLingua (2020). Sprachlernmethoden: 4 die für alle Sprachen funktionieren. https:// www.mosalingua.com/de/methoden-zum-sprachenlernen/

[31] Faßbinder, K. (2020). Grundlagen und Faktoren des Fremdsprachenerwerbs. https://www. sprachenlernen24.de/blog/voraussetzungen-lernen-fremdsprache/

[32] How online learning differs from distance learning. https://finacademy.net/materials/ article/chem-otlichaetsya-onlajn-obuchenie-ot-distantsionnogo-obucheniya

[33] Tselischeva, E. (2014). Distance learning is one of the forms of organization of the educational process. https://videouroki.net/razrabotki/distantsionnoe-obuchenie-kak-odna-izform-organizatsii-uchebnogo-protsessa.html

[34] Gorovenko, L.A., Aleksanyan, G.A. (2018). Organization of distance learning using Internet technologies. Bulletin of the Adygeya state University. Series "Natural-mathematical and technical Sciences", 4: 220-225.

[35] Guz, Yu.A., Shevchenko, V.V. (2015). Effectiveness and prospects of development of distance learning in foreign languages. In the collection: The magic of innovation: new study of the language and methodology of its teaching. Materials of the Second scientific and practical conference, pp. 471-475.

[36] Department for Education, Government of the UK (2013). Statutory guidance. National curriculum in England: languages programmes of study. https://www.gov.uk/government/ publications/national-curriculum-in-england-languages-progammes-of-study/national-curri culum-in-england-languages-progammes-of-study https://doi.org/10.4324/978131503035 $\underline{7-8}$

[37] $\overline{\mathrm{Guz}}$, Yu.A. (2017). Effective use of mobile applications and tablets in foreign language teaching. Azimut of scientific research: pedagogy and psychology, 6(4): 59-62.

[38] Rybalkina, P.V. (2017). Project thinking as a new cultural phenomenon. Scientific Bulletin of the Belgorod state University. Ser. Philosophy. Sociology. Law, 3(258): 158-161.

[39] Aleshkina, O.V., Minalieva, M.A., Rachiteleva, N.A. (2015). Remote educational technologies-the key to mass education of the XXI century. In Scientific Conference: Actual problems of pedagogy: materials of the VI international conference. Young scientist Publishing house, Chita, pp. 63-65.

[40] Kapovsky, V.L. (2015). Distance education. World experience. ASU Bulletin, 1(157): 2430.

[41] Nixon, C., Tomlinson, M. (2008). Kid's Box. CUP, 2008.

[42] Alwaely, S., \& Lahiani, H. (2020). Assessing Argumentative Writing Skills in Online Environments among Arabic Language Teachers of Grades 5 to 7 in UAE Schools. International Journal of Emerging Technologies in Learning (iJET), 15(18): 202-217. https://doi. org/10.3991/ijet.v15i18.13581

[43] Kiyan, I.V. (2010). Analysis of foreign experience of distance learning. Energy security and energy saving, 6(36): 32-36.

[44] Avramenko, E., Tsebrovskaya, O. (2020). Experts have compared the transition to distance learning in different countries of the world. https://riafan.ru/1271584-eksperty-sravniliperekhod-na-distancionnoe-obuchenie-v-raznykh-stranakh-mira

[45] Trade union organization of employees of UdSU. https://profcom.udsu.ru 
[46] Kuban State Technological University (2020). Evaluation of e-learning and distance learning technologies. https://kubstu.ru/r-9040

[47] Sykes, J., Oskoz, A., Thome, S.L. Web 2.0, Synthetic Immersive Environments, and Mobile Resources. CALICO Journal, 25(3): 528-546. https://doi.org/10.1558/cj.v25i3.528$\underline{546}$

[48] Online Bildung (2019). Mateab Onliene Kurs für Anfänger und Studenten - Mateab Online Kurs im Vergleich. https://online-bildung.org/matlab-online-kurs-fuer-anfaengerund-studenten-matlab-online-kurse-im-vergleich/ https://doi.org/10.1007/978-3-322$\underline{86646-25}$

\section{Authors}

Kolyada Nataliya Alexandrowna is a $\mathrm{PhD}$ in Philosophical Sciences, Associate Professor of the Southern Federal University, Rostov on Don, Russia.

Shapovalova Larisa Ivanovna is a Doctor of Pedagogical Sciences, Professor of the Southern Federal University, Rostov on Don, Russia.

Guz Yuliya Alexeevna is a $\mathrm{PhD}$ in Pedagogical Sciences, Associate Professor of the Southern Federal University, Rostov on Don, Russia.

Melkonyan Ashkhen Arutjunovna is a $\mathrm{PhD}$ in Pedagogical Sciences, Associate Professor of the Southern Federal University, Rostov on Don, Russia.

Article submitted 2020-09-07. Resubmitted 2020-10-27. Final acceptance 2020-10-29. Final version published as submitted by the authors. 